\title{
Efficiency of Guidance and Counseling Departments in Promotion of Discipline in High Schools in Kiambu County, Kenya
}

\author{
Pullah Mitto Tiego \\ Phd Candidate, Educational Management, Researcher, \\ Counseling Research Institute of Kenya, P.O. Box 770, 00200, Nairobi, Kenya \\ Corresponding Author Email: pullahmtiego@gmail.com \\ Stephen Kiriungi Kamore \\ MA Candidate, Counseling Psychology, Researcher, \\ Counseling Research Institute of Kenya, P.O. Box 770, 00200, Nairobi, Kenya \\ Email: kamorestephenkiriungi@yahoo.com / info@crikeonline.org
}

Doi:10.5901/ajis.2015.v4n3p301

\begin{abstract}
This research probes pertinent issues pertaining to the efficiency and role of Guidance and Counseling in tackling cases of indiscipline in high schools in Kiambu County. A cross sectional parallel sample survey design was used. A total of 31 respondents from high schools in Kiambu County were randomly sampled. The respondents were either teachers or heads of department from Guidance and Counseling. This research endeavors to establish the professional grounding and knowledge of teachers in Guidance and counseling departments in high schools in Kiambu. The capacity of the respondents was investigated. The research also looked at the relationship between budgetary allocation and efficiency of the department in school discipline.
\end{abstract}

Keywords: Discipline, Guidance, Counseling, Efficiency and Capacity

\section{Introduction}

\subsection{Background Information}

A comprehensive school counseling programs address strategies to enhance academics, provide career awareness, develop employment readiness, encourage self- awareness, foster interpersonal communication skills, and impart life success skills for all students and are a critical component of every students' school experience. Dahir, C. (2009) A study by Onderi \& Makori (2013), identified teenage pregnancy, bullying, alcohol and drugs, violence and truancy, among others as serious issues confronting principals and that such challenges and issues negatively impacted on the schools' entire life, including examination performances.

There have been increased reports in the local newspapers in Kenya about violence in secondary schools. These reports give accounts of bullying, occult practices, drug abuse, multiple homicides, destruction of property, riots and strikes and unscheduled closures in schools. Among the reasons for this aggravated situation is lack of guidance from parents and teachers Nyutu, P. N \& Gysbers, N.C. (2008).

A study conducted among public high school teachers and students in Kenya revealed that Guidance and Counseling programs were not effective partly because of inadequate training, less time and lack of support from the administration. Ngumbi, E. (2012).

In a research conducted in Siaya District of Kenya, it was found that, guidance and counseling program had inadequately contributed to the students' social adjustment as a result of inadequate facilities, and ineffective strategies of guidance and counseling were being used in schools. Auni, R.T. et al (2014)

Ajowi, J.O. \& Simatwa, E.M.W. (2010), in their research which examined the role of guidance and counseling in promoting students discipline in secondary schools in Kisumu, Kenya, found out that guidance and counseling was minimally used to promote student discipline in secondary schools in Kisumu. It also found that there was no policy guideline from the Ministry of Education on how the schools could use guidance and counseling to manage the student 
disciplinary cases.

In research findings conducted in Murang'a County, Tiego,P.M \& Kamore, S.K. (2014), identified among factors leading to strikes and unrest in schools, teachers' narrow view and understanding of discipline, popularity and persistent use of corporal punishment despite its abolishment and school administrators and teachers being major indirect contributors to indiscipline in schools.

The National Conference of State Legislature and the American Association for Counseling and Development recently collaborated on a report advocating elementary school counseling programs to provide a window of opportunity for educating policymakers about the components of comprehensive school counseling programs and the appropriate role of school counselors. Borders, L.M \& Drury, S. M. (1992)

School counselors have been conspicuously absent from educational reform reports and are often viewed as peripheral to the main function of schooling and academic achievement. Stone, C.B \& Clark, M.A. (2001), point out that school counselors and principals have not traditionally viewed one another as partners in educational leadership, yet they can be powerful allies for school reform, focusing on helping students understand and meet more rigorous academic standards.

The American School Counselor Association (ASCA) National Model: A Framework for Comprehensive School Counseling Program specifically included school counselors' practices of data usage, program evaluation, advocacy, collaboration, systemic change, and leadership, all elements vital to a school counseling program that will fruitfully effect school improvement and student achievement. Mason, E (2010).

ASCA recommends a counselor-student ratio of 1:250 and that professional school counselors should be educators certified with license with a minimum of masters degree in school counseling, making them uniquely qualified to address all students' academic, personal, social and career needs by designing, implementing evaluation and enhancing a comprehensive school counseling program that supports students' growth. Auni, et al.

\subsection{Statement of the problem}

Kiambu County has been particularly prominent in media in matters concerning school discipline. Many high schools in Kiambu have boycotted classes, gone on rampage and destroyed property. Often, these schools would be closed indefinitely, losing many man hours in class work and opportunity, large amounts of money in reconstruction of destroyed property and untold stories of suffering and inconvenience. This same scenario is reflected in many other counties across the country though at varying extents. It is an issue of national concern and significance. The purpose of this research is to find out the role played by the department of Guidance and Counseling in minimizing or curtailing this menace.

\subsection{Objectives}

1. To investigate specific knowledge of counseling, among high school teachers in charge of the Guidance and counseling department in Kiambu

2. To probe the capacity of teachers manning the department in high schools in Kiambu

3. To find out the budgetary allocation and its implications to the department of Guidance and Counseling in high schools in Kiambu County

\subsection{Research Questions}

1. How knowledgeable about Guidance and Counseling are teachers in the department in high schools in Kiambu County?

2. What is the capacity of the teachers manning the activities of Guidance and counseling department in high schools of Kiambu?

3. What are the budgetary allocation and its implications to the Guidance and counseling departments in high schools in Kiambu County?

\subsection{Theoretical Framework}

This study was grounded on systems' theory. This theory sees school discipline as a system involving many stakeholders including counselors. With abolition of corporal punishment in schools, the role of counselors in schools should be 
enhanced. School discipline is a complex issue that is often not understood because it involves many stakeholders and complicated circumstances Tiego et al

\section{Methodology}

The study population comprised of 31 teachers and heads of Guidance and Counseling departments from 31 high schools in Kiambu County. The teachers and HODs were randomly sampled from secondary schools from the county. Indepth interviews were conducted in a workshop held to discuss issues of discipline with the same respondents. Interviews were also held with a senior Ministry of education official and two county officials.

\subsection{Instruments}

Two instruments were used to collect data for the study. These were the questionnaires and in-depth interview schedule. The same questionnaire was used for both teachers and heads in the guidance and counseling department.

The questionnaire had 40 open and closed-ended questions. The questions probed the general background of the respondents and their grounding in counseling. The questionnaire also needed to know the capacity of these school counseling teachers and the budgetary allocation to their department and what implication this had on the efficiency of the department

A focused group interview was held with the same respondents in a workshop at a location in the county. This approach was especially detailed and informative, if not exhaustive.

An in-depth interview was also held with senior ministry official in charge of Guidance and counseling at the ministry of education national headquarters (Nairobi), the County Director of Education and the County Quality Assurance and Standards Official (CQUASO), Kiambu

\subsection{Validity and Reliability}

Validity of the instruments was ascertained by making sure that items on the instruments were well constructed and sufficiently addressed each research question of the study.

Reliability of the focused and in-depth interviews was determined by making them comprehensive and exhaustive in terms of the research questions and the answers sought.

\section{Results and Discussions}

\subsection{Teacher counselor's knowledge about guidance and Counseling}

In the study respondents were asked to define two terms "Guidance" and "Counseling" It's evident from the definitions given by the respondents that many teachers in charge of guidance and counseling departments are not professionally trained in counseling. The answers given by the teachers betray lack of sound basic knowledge of what guidance and counseling is all about.

The survey further probed how well teachers are aware of the roles of guidance and Counseling department in addressing school discipline issues. The respondents' responses are summarized in table 1 below.

Table 1: Roles of the Guidance and Counseling Department

\begin{tabular}{|c|c|c|}
\hline Evaluating the school counseling needs & $27 / 31$ & $87 \%$ \\
\hline Developing G/C programs & $24 / 31$ & $77 \%$ \\
\hline Counseling students with discipline issues & $24 / 31$ & $77 \%$ \\
\hline Giving advice to the administration on how to handle indiscipline cases through counseling and guidance programs & $22 / 31$ & $71 \%$ \\
\hline Referral & $1 / 31$ & $3 \%$ \\
\hline
\end{tabular}

The study findings indicate that teachers seemed to be aware with the roles of the department; however the paradox is in the implementation of the same. It is equally interesting to note that only one counselor thought the role of the department is to make referrals

The study investigated the teacher counselors' awareness on the effectiveness of guidance and counseling in 
dealing with school discipline. Responses vividly revealed that the guidance and counseling departments do not adequately deal with discipline issues. In rating the success of the department in dealing with school discipline, $26 \%$ rated it successful, 35\% rated it fair and 32\% rated it wanting. The respondents in an open question gave reasons for their ratings as follows;

\section{Reasons for Fair}

- Incompetent personnel

- Many indiscipline cases are handled by the administration and rarely referred to guidance and counseling department

- Guidance and counseling department has failed to prevent / control students unrest

- Many students with discipline issues have negative attitude toward guidance and counseling.

- Guidance and counseling only works in some issues / students while others don't respond positively after counseling.

- Students who are disciplined find it challenging to accept counseling services

- Teacher counselors don't get adequate time to deal with the many cases of students involved in indiscipline due to high work load. Many students therefore are never attended.

- Sometimes there is conflict of approach between discipline committee and Guidance and counseling teachers. Discipline teachers perceive counseling approach as too soft to change students behaviors

- Guide and counseling programs are not adequately supported by school administration and teachers

Reasons for Wanting

- It's difficult to differentiate between discipline and counseling

- Guidance and counseling services are left to few teachers who are overwhelmed by the responsibility. Majority of the teachers don't perceive guidance and counseling as their professional responsibility.

- Some other cruel forms of punishments seem to be more effective than counseling such as canning, expulsion and corporal punishments.

- The teachers in charge of school discipline tend to ignore the contribution of Guidance and Counseling department when handling students with discipline problems

- In some schools Guidance and Counseling services are given very low deals. No budget to equip the department and no time created for guidance and counseling.

- The teacher counselors are frustrated by some uncooperative school administrators who views guidance and counseling as a weak soft and ineffective approach to school discipline

Reasons for Successful

- Many students with discipline issues have benefited from Guidance and Counseling services where the teachers counselors are competent.

- Counseling has succeeded in unearthing deep rooted issues in the life of students with discipline issues

The study probed about the teachers understanding of the relationship between discipline and counseling. The bar graph below summarizes the findings:

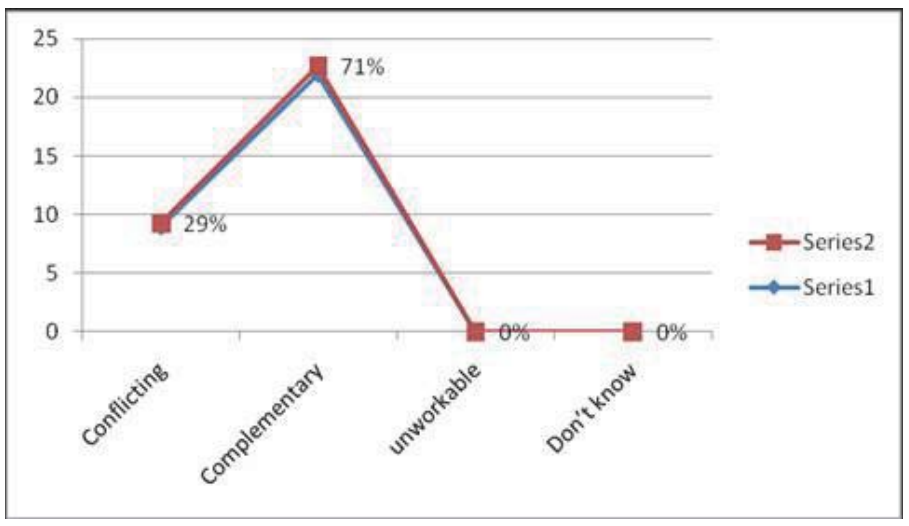


The finding are evidence that majority of the respondents saw a correlation between discipline and counseling.

The study enquired about the people targeted by the school discipline guidance and counseling programs. The finding indicate that $84 \%$ of G/C programs targets students, $29 \%$ targets parents, $23 \%$ targets teachers 1 and $10 \%$ targets support staff. It can be concluded that the guidance and counseling discipline programs in most schools focuses on the students and minimally on other stakeholders in the schools yet they contribute greatly to school discipline. This is evidence that teachers do not perceive school as a system that needs school wide discipline programs targeting all stakeholders.

The study in an open question asked the participants to list the discipline issues that are commonly handled by guidance and counseling teachers in secondary schools. The following discipline issues were identified

- Truancy

- Coupling in mixed schools

- Conflict among students

- Chronic absenteeism

- Missing lessons

- Theft in school

- Destruction of school properties and facilities

- Deviance to authority

- Lesbianism / homosexuality

- Violence / fighting

- Pregnancy

- Rudeness to teachers

- Sneaking out of school

- Drugs and substance abuse

- Apathy ( don't care attitude)

- Addiction to pornography

- Early marriages ( mostly day schools)

- Negative peer pressure

- Cultism

- Joining outlawed movements / gangs

- Bullying

- Academic indiscipline / failure to do assignments/ homework

- Chronic lateness

Through interviews with the respondents it was evident that teachers don't feel competent in handling some discipline issues like deviant sexual behaviors, cultism, bullying, drugs and substance abuse and addiction and defiance behaviors requires.

The study investigated the teacher counselors' awareness of the challenges hindering the effectiveness of the guidance and counseling departments in addressing discipline issues in school. The table below shows their responses:

Table 2: Challenges facing the guidance and counseling departments

\begin{tabular}{|c|c|c|}
\hline Lack of support by the school administration & $10 / 31$ & $32 \%$ \\
\hline Lack of training & $20 / 31$ & $65 \%$ \\
\hline Due role conflicts & $15 / 31$ & $48 \%$ \\
\hline Lack of counseling room and facilities & $15 / 31$ & $48 \%$ \\
\hline Lack of adequate time to handle students with indiscipline issues & $28 / 31$ & $90 \%$ \\
\hline Conflict with school discipline policies & $15 / 31$ & $48 \%$ \\
\hline Negative attitude about guidance and counseling by students & $16 / 31$ & $52 \%$ \\
\hline Lack of support by parents & $12 / 31$ & $39 \%$ \\
\hline Lack of support by teachers & $9 / 31$ & $29 \%$ \\
\hline Lack of clear government policies on implementation, coordination and support of G/C services in schools & $24 / 31$ & $77 \%$ \\
\hline
\end{tabular}

It is noteworthy from the study findings that the respondents identify lack of adequate time to handle and counsel the students with discipline issues as the main challenge. The second most important reason for inadequate performance by 
the department is lack of clear government policies on coordination and support of Guidance and counseling services in schools. Equally, lack of training is also highlighted and emphasized

\subsection{The capacity of the teachers manning the Guidance and counseling departments?}

The study probed the competency of the teachers manning guidance and counseling departments. In the questionnaire teachers were asked to indicate their level of professional training as teachers and as teacher counselors. The table below shows their responses:

Table 3: Level of education

\begin{tabular}{|l|c|c|}
\hline Level & Frequency & Percentage \\
\hline Bachelor & 22 & $71 \%$ \\
\hline Masters & 4 & $13 \%$ \\
\hline High diploma & 4 & $13 \%$ \\
\hline Certificate & 1 & $3 \%$ \\
\hline
\end{tabular}

From the findings it's evident that most teachers are not trained in professional counseling courses. Only one with masters in counseling related two with high diploma in $\mathrm{G} / \mathrm{C}$, One with certificate in counseling related course. All the others are only trained in education as professional teachers

Table 4: Mode of study

\begin{tabular}{|l|c|c|}
\hline Mode & Frequency & Percentage \\
\hline Full time & 17 & $55 \%$ \\
\hline School based & 8 & $26 \%$ \\
\hline Open learning & 5 & $16 \%$ \\
\hline Not indicated & 1 & $3 \%$ \\
\hline
\end{tabular}

The few respondents trained in professional counseling courses studied during the school holidays.

The study probed how the teachers manning guidance and counseling departments acquire their competency. Their responses are indicated in table 4 below;

Table 5: Ways of enhancing competency

\begin{tabular}{|l|c|c|}
\hline Professional training & $4 / 31$ & $13 \%$ \\
\hline Experience & $17 / 31$ & $55 \%$ \\
\hline Seminars and workshops & $22 / 31$ & $71 \%$ \\
\hline Refresher courses & $3 / 31$ & $10 \%$ \\
\hline
\end{tabular}

The majority of teacher counselors had acquired some paltry training and experience through rare seminars and workshops. This gives a clear indication of the status of the capacity of the respondents.

The study probed deeply on how the teachers training adequately prepare them to handle some selected programs perceived as essential in running an effective guidance and counseling department in schools. Using the scale below ranging from 1- 5, respondents were asked to indicate their perception of the level of academic preparation they received by their professional training programs on each of the given issue. The respondents' responses are summarized in table 6 below.

1. Not well prepared

2. Minimally prepared

3. Adequately prepared

4. Well prepared

5. Very well prepared 
Table 6: Teachers perception on their the level of academic preparation they received by their professional training programs

\begin{tabular}{|c|c|c|c|c|c|c|}
\hline & & 1 & 2 & 3 & 4 & 5 \\
\hline 1 & Counseling students with drug and substance abuse problem & $\begin{array}{l}9 / 31 \\
29 \%\end{array}$ & $\begin{array}{c}14 / 31 \\
45 \%\end{array}$ & $\begin{array}{l}6 / 31 \\
19 \%\end{array}$ & $\begin{array}{c}1 / 31 \\
3 \%\end{array}$ & $\begin{array}{c}1 / 31 \\
3 \%\end{array}$ \\
\hline 2 & Counseling students on effective conflict resolution & $\begin{array}{l}7 / 31 \\
23 \%\end{array}$ & $\begin{array}{l}8 / 31 \\
26 \%\end{array}$ & $\begin{array}{c}10 / 31 \\
32 \%\end{array}$ & $\begin{array}{l}4 / 31 \\
13 \%\end{array}$ & $\begin{array}{c}2 / 31 \\
6 \%\end{array}$ \\
\hline 3 & Counseling students with discipline problems & $\begin{array}{c}10 / 31 \\
32 \%\end{array}$ & $\begin{array}{c}12 / 31 \\
38 \%\end{array}$ & $\begin{array}{l}3 / 31 \\
9.6 \%\end{array}$ & $\begin{array}{l}4 / 31 \\
13 \%\end{array}$ & $\begin{array}{c}2 / 31 \\
6 \%\end{array}$ \\
\hline 4 & Assessing students with behavioral or conduct disorders & $\begin{array}{c}16 / 31 \\
52 \%\end{array}$ & $\begin{array}{c}12 / 31 \\
39 \%\end{array}$ & $\begin{array}{c}1 / 31 \\
3 \%\end{array}$ & $\begin{array}{c}1 / 31 \\
3 \%\end{array}$ & $\begin{array}{c}1 / 31 \\
3 \%\end{array}$ \\
\hline 5 & Planning and implementing guidance and counseling programs in schools & $\begin{array}{l}6 / 31 \\
19 \%\end{array}$ & $\begin{array}{c}17 / 31 \\
19 \%\end{array}$ & $\begin{array}{l}5 / 31 \\
16 \%\end{array}$ & $\begin{array}{c}1 / 31 \\
3 \%\end{array}$ & $\begin{array}{c}2 / 31 \\
6 \%\end{array}$ \\
\hline 6 & Coordinating $\mathrm{G} / \mathrm{C}$ programs in schools & $\begin{array}{l}7 / 31 \\
23 \%\end{array}$ & $\begin{array}{l}8 / 31 \\
26 \%\end{array}$ & $\begin{array}{l}8 / 31 \\
26 \%\end{array}$ & $\begin{array}{c}6 / 3 \\
19 \%\end{array}$ & $\begin{array}{c}2 / 31 \\
6 \%\end{array}$ \\
\hline 7 & Crisis management (strikes) & $\begin{array}{c}20 / 31 \\
65 \%\end{array}$ & $\begin{array}{l}8 / 31 \\
26 \%\end{array}$ & $\begin{array}{c}2 / 31 \\
6 \%\end{array}$ & $\begin{array}{c}0 / 31 \\
0 \%\end{array}$ & $\begin{array}{c}1 / 31 \\
3 \%\end{array}$ \\
\hline 8 & Identifying school policies that hinder effective school discipline & $\begin{array}{l}4 / 31 \\
13 \%\end{array}$ & $\begin{array}{c}16 / 31 \\
51 \%\end{array}$ & $\begin{array}{l}8 / 31 \\
26 \%\end{array}$ & $\begin{array}{c}1 / 31 \\
3 \%\end{array}$ & $\begin{array}{c}2 / 31 \\
6 \%\end{array}$ \\
\hline 9 & Assessing school guidance and counseling needs & $\begin{array}{c}19 / 31 \\
61 \%\end{array}$ & $\begin{array}{l}6 / 31 \\
19 \%\end{array}$ & $\begin{array}{c}2 / 31 \\
6 \%\end{array}$ & $\begin{array}{c}1 / 31 \\
3 \%\end{array}$ & $\begin{array}{l}3 / 31 \\
10 \%\end{array}$ \\
\hline
\end{tabular}

The teacher counselors felt inadequate and minimally prepared in assessing school guidance and counseling needs, crisis management, and assessing students with behavioral and conduct disorder. Adequately prepared, well prepared and very well prepared rated lowly. This findings support the fact that teachers manning guidance and counseling departments are not competent enough.

The study probed the frequency of capacity building seminars and workshops organized to enhance the competency of the teacher counselors. The responses of the respondents were as indicated in Table 7 below.

Table 7: The frequency of counseling and discipline workshops for the last four years

\begin{tabular}{|c|c|c|}
\hline 1 & $2 / 31$ & $6 \%$ \\
\hline 2 & $5 / 31$ & $16 \%$ \\
\hline 3 & $3 / 31$ & $10 \%$ \\
\hline 4 & $3 / 31$ & $10 \%$ \\
\hline Above 4 & $4 / 31$ & $13 \%$ \\
\hline None & $14 / 31$ & $45 \%$ \\
\hline
\end{tabular}

The study findings revealed that majority of the respondents (45\%) had not attended any professional seminar or workshop on school counseling and discipline in the last four years to the date of this survey. The finding supports the lack of competency of the teachers running the guidance and counseling departments in secondary schools.

In an open question the respondents were the respondents were asked to suggest area of training that would be useful in enhancing their competency in handling school discipline more effectively. The following were the areas of training identified by the respondents:

- Life skills

- Conflicts management

- Integrating discipline and counseling

- Crisis management in schools

- Parenting skills

- Basic counseling skills

- Trauma and debriefing

- Communication skills

- Coping with single parenthood

- Counseling HIV positive students 
- Effective study methods

- Career guidance and counseling

- Attitude development

- Emerging issues and adolescence behaviors

- Dual role and school counseling

- Drugs and behaviors addiction and rehabilitation

- Good working relationships

- Counseling students with sexual deviant behaviors ( homosexuality / lesbianism)

The respondents in an open question were asked to suggest some possible remedies the ministry of education policy makers can take to improve $\mathrm{G} / \mathrm{C}$ services and enhance discipline in schools. The following suggestions were given but not in any order.

- Make guidance and counseling compulsory for teachers in training

- Government should sponsor training for teachers in G/C

- Create professional referral centres for students with issues beyond the school counselors capacity

- Give responsibility allowance to $\mathrm{G} / \mathrm{C}$ teachers

- School administration to take G/C departments seriously and allocate a budget to cater for the programs and facilities

- Schools to create time for $\mathrm{G} / \mathrm{C}$ in the school routines

- Organize conferences and seminars for $G / C$ teachers to share experiences and challenges

- Schools to reduce teaching workload for school counselors

- The Ministry to develop clear policies to run and manage G/C services in schools

- Schools to create an office of the dean of students to cater for the welfare of the students

\subsection{The budgetary allocation and its implication to the Guidance and Counseling departments.}

The study probed on the relationship between the budgetary allocation and the motivation of the teachers manning guidance and counseling department in secondary schools. The respondents were asked to rate their motivation in offering quality guidance and counseling services to the schools. Their responses were as indicated in table 8 below.

Table 8: Level of teacher counselors' motivation

\begin{tabular}{|l|c|c|}
\hline Highly motivated & $0 / 31$ & $0 \%$ \\
\hline Lowly motivated & $11 / 31$ & $35 \%$ \\
\hline Not motivated & $20 / 31$ & $65 \%$ \\
\hline
\end{tabular}

A whopping $65 \%$ of the respondents felt that they are not motivated at all and the other $35 \%$ are lowly motivated. What is the impact of this on the efficiency of the G/C performance?

The respondents were asked in an open question to suggest reasons for their lack motivation in offering quality guidance and counseling services in their respective schools. The following were their responses;

1. Lack of budget for $\mathrm{G} / \mathrm{C}$ department

2. Lack of a support by school administration in planning and implementing $\mathrm{G} / \mathrm{C}$ programs in schools

3. Lack of cooperation among the teachers in $\mathrm{G} / \mathrm{C}$ programs

4. Lack of adequate time for $\mathrm{G} / \mathrm{C}$ programs in many schools

5. Lack of appreciation of $\mathrm{G} / \mathrm{C}$ teachers and the services they give to schools

6. Most head of $\mathrm{G} / \mathrm{C}$ departments are internally appointed and no recognition by the T.S.C

7. High teaching workload for teachers in charge of $\mathrm{G} / \mathrm{C}$

8. No frequent professional capacity building seminars and workshops for school counselors

9. No counseling rooms and facilities in many schools

10. Negative attitude toward by teachers toward $\mathrm{G} / \mathrm{C}$ services in schools

11. Many schools administrators don't support $\mathrm{G} / \mathrm{C}$ teachers for professional seminar and workshops

The responses given by the respondents are directly related with the financial allocation to the guidance and counseling departments especially lack of counseling rooms and facilities and financing teachers' attendance to capacity building seminars and workshops as a ways of enhancing their competency. It can be concluded that the perceived lack 
of support by the school administration in implementing the guidance and counseling programs could imply lack of budgetary allocation in the school budget among other forms of support.

The study further probed the opinions of the respondents on the best ways of motivating schools counselors to ensure they are committed and effective in offering quality guidance and counseling services especially in enhancing school discipline. The suggestions of the respondents are summarized by table 9 below;

Table 9: Suggested ways of motivating teacher counselors

\begin{tabular}{|l|c|c|}
\hline Sponsor them for professional growth seminars/ workshops and conferences & $23 / 31$ & $74 \%$ \\
\hline Reduce their teaching workload & $27 / 31$ & $87 \%$ \\
\hline Give them special allowances for the extra responsibility in offering G/C services & $24 / 31$ & $77 \%$ \\
\hline Provide proper counseling rooms, equipments and reference materials & $26 / 31$ & $84 \%$ \\
\hline Schools to create budget to support the G/C programs & $24 / 31$ & $77 \%$ \\
\hline Schools to support the training of students peer counselors & $26 / 31$ & $84 \%$ \\
\hline Putting in place polices to guide G/C services in schools & $27 / 31$ & $87 \%$ \\
\hline
\end{tabular}

The study found that most of the suggested ways of motivating teacher counselors by the respondents have a direct implication on the budgetary allocation. Only two out the seven suggested ways to motivate teacher counselors have no direct monetary implication these are reducing the teaching load of teacher counselors and putting in place policies to guide $\mathrm{G} / \mathrm{C}$ services in schools. This shows clearly that there is close relationship between budgetary allocation and efficiency of the guidance and counseling services in schools.

The study enquired from the respondents if their respective schools do have budgets for guidance and counseling department and how much money is allocated. 19\% of the schools represented do have budgetary allocation for guidance and counseling department while $81 \%$ of the schools don't have budgetary allocation. The table 10 below show the amount of money allocated to guidance and counseling departments.

Table 10: Average Amount of money allocated to guidance and counseling departments

\begin{tabular}{|l|c|c|}
\hline Below 10,000 & $2 / 31$ & $6 \%$ \\
\hline $10,000-20,000$ & $8 / 31$ & $26 \%$ \\
\hline $21,000-40,000$ & $1 / 31$ & $3 \%$ \\
\hline $40,000-100,000$ & $1 / 31$ & $3 \%$ \\
\hline Above 200,000 & $1 / 31$ & $3 \%$ \\
\hline None & $18 / 31$ & $59 \%$ \\
\hline
\end{tabular}

The study found that the schools with budgetary allocations the amount given was less than Kshs 20,000 . The budgetary allocations depict the attitude of school administration toward this crucial department and confirm why the guidance and counseling departments in schools suffers such low morale and performance.

\section{Conclusion}

A combination of three factors, namely, poor comprehensive background information knowledge, serious incapacity of the personnel manning Guidance and Counseling departments, negative attitude and poor budgetary allocation undermines the efficiency of that vital departments' contribution to school discipline and academic excellence. It is evident that what goes on in schools in Kiambu County is a replica of the situation in all other counties in the country.

\section{Recommendations}

1. Research can be conducted targeting the policy environment and its contribution in weakening Guidance and Counseling departments in high schools in Kenya

2. Another research should focus on the attitude of the administration or the principal in particular and the teachers towards the role and contribution of the Guidance and Counseling, not only towards the school discipline but the overall academic performance of the school.

3. The teachers appointed to head that department should be not only trained and competent but interested and 
determined to make the difference in the lives of all students

4. The Principals should cease their negative attitude towards and instead forge a collaboration with the guidance and counseling department to improve the school discipline and academic performance

5. Timetable should be made in such a way that members of the department have ample time to engage the students and other members of the school fraternity in counseling sessions.

6. There is urgent need for customer based professional seminars and workshops to enhance the capacity of the teachers manning guidance and counseling departments.

7. The schools should implement the recommendation of the basic education act 2013 that requires the schools boards of managements to facilitate and ensure the provision of guidance and counseling to all learners.

8. Schools school develop school wide guidance and counseling programs targeting all the stakeholder as a sustainable measure to address the perennial school discipline challenges

\section{References}

Ajowi, J. O. and Simatwa, E. M. W (2010). The Role of Guidance and Counseling in Promoting Student Discipline in Secondary Schools in Kenya: A case Study of Kisumu District. Educational Research and Reviews, Vol.5 (5) Pg. 263-272

Auni, R.T.,Songok, Jepchirchir,R., Odhiambo, O. R, Nabwire \& Lyanda, J. (2014). Determinants of Guidance and Counseling Programme in Addressing Students Social Adjustment in Secondary Schools in Siaya District, Kenya. Internatonal Journal of Humanities and Social Science. Vol. 4. No.4, Pg. 69-76

Borders, L. D. and Drury, S. M. (1992), Comprehensive School Counseling Programs: A Review for Policymakers and Practitioner, Journal of Counseling and Development, Vol.70,Pg 23-24

Dahir, C. (2009), Comprehensive School Counseling Program Guide. Working Document. Springfield Public Schools

Mason E. (2010), Leadership Practices of School Counselors and Counseling Program Implementation, NASSP Bulletin 94(4) pg 274285

Ngumbi, Elizabeth (2012), Counseling in Public High Schools: Policy, Practice and Research in Kenya. All Academic Inc.

Nyutu, P.N. \& Gysbers, N.C. (2008). Assessing the Counselling Needs of High School Students in Kenya. International Journal of Educational Vocational Guidance, Vol 8, pg 83-94

Onderi, H. and Makori, A (2013) Secondary School Principals In Nyamira County in Kenya: Issues and Challenges. Educational Research International Vol. 1 No. 1 pg. 67-90

Stone, C. b. and Clark, M.A. (2001), School Counselors and Principals: Partners in Support of Academic Achievement, National Association of Secondary School Principals (NASSP) Bulletin 85:46

Tiego, P. M. and Kamore, S. K. (2014) Factors Leading To Strikes and General Indiscipline in High Schools in Kenya: Case of Murang'a County. Pinnacle Educational Research and Development. Vol.2 (5) pg 1-6 